Tóth, Zsuzsanna. "The Hungarian Peculiarities of National Remembrance: Historical Figures with Symbolic Importance in Nineteenth-century Hungarian History Paintings." AHEA: E-journal of the American Hungarian Educators Association, Volume 5 (2012): http://ahea.net/e-journal/volume-5-2012

\title{
The Hungarian Peculiarities of National Remembrance: Historical Figures with Symbolic Importance in Nineteenth-century Hungarian History Paintings
}

\section{Zsuzsanna Tóth, University of Szeged (SZTE)}

\begin{abstract}
In order to place nineteenth-century Hungarian art into international context, this article calls for the theoretical discourse of cultural memory, when a suppressed community turns to their past and insists on their antecedents' traditions for the survival of their culture. When, in the 1850s and 1860s, the leaders of the Habsburg Austrian Empire retaliated against Hungary for its 1848-49 "Fight for Freedom", Hungarian visual art of the era rediscovered long-honoured figures of the historical past as the essential components of Hungarian national identity. This article argues that the successful visualization and memorialization of outstanding historical characters with symbolic values for the Hungarian nation was due to history painting itself as medium. The Hungarian painters' choice of characters vigorously reacted to the changing political relationship between the Austrians and the Hungarians from the failure of the 1849 Hungarian Fight for Freedom until the 1850s and the 1870s involving the 1867 Austro-Hungarian Compromise. Keeping it in mind, the display and the reception of four great paintings, Bertalan Székely's The Discovery of the Body of King Louis II (1860), Viktor Madarász's Péter Zrínyi and Ferenc Frangepán in Prison at Wiener-Neustadt (1864), Székely's The Women of Eger (1867) and Gyula Benczúr's The Baptism of Vajk (1875) are analysed.
\end{abstract}

Keywords: Hungarian history painting, cultural memory, nationhood, national symbolism, reception

Biography: Zsuzsanna Tóth is a Ph. D. Candidate in the British and American Literature and Culture Programme at the Doctoral School of Literary Studies, University of Szeged (SZTE), in Hungary. Her research interests are religious symbolism, cultural memories in GrecoRoman and Judeo-Christian traditions, and theories of verbal and visual representations. She is currently conducting research on Philip Pullman's book trilogy, His Dark Materials (19952000). She holds an M.A. degree in English Language and Literature and English Language Education from the University of Szeged, where she also completed a specialization as a Hungarian Studies Instructor for Foreigners.

Foreigners are usually interested in those parts of Hungarian culture that are considered to be unique in their cultural horizons; one of the best examples may be nineteenth-century Hungarian history painting created in the context of National Romanticism, under the domination of the Habsburg Empire. However, the comprehension of this genre vigorously reacting to contemporary political and social movements requires not only the knowledge of the depicted events' and characters' political role in Hungarian history, but also the knowledge of these events' and characters' symbolic significance in the Hungarian national cultural heritage. For this reason, this article focuses on the special circumstances that led to the ascension of once lived men and women - in particular King Saint Stephen I (cc. 967-1038) and Louis II (1506-1526), Péter Zrínyi (1621-1671) and Ferenc Frangepán (1620-1671) and the heroines of the victorious Battle of Eger (1552) - to the status of the Hungarian nation's either tragic or glorious heroes and heroines as the constituents of Hungarian nationhood. This process of symbolization is best observed in the 
Tóth, Zsuzsanna. "The Hungarian Peculiarities of National Remembrance: Historical Figures with Symbolic Importance in Nineteenth-century Hungarian History Paintings." AHEA: E-journal of the American Hungarian Educators Association, Volume 5 (2012): http://ahea.net/e-journal/volume-5-2012

objects of nineteenth-century visual culture whose most recognized representative was the genre of history painting. In accordance with these, this article argues that the successful visualization and memorization of outstanding historical characters with symbolic values for the Hungarian nation is due to its medium, well-known Hungarian history paintings in the frame of nineteenth-century National Romanticism. Characteristically to East-Central European nations with 'difficult' history, these processes were realized in correlation with the current political circumstances of Hungary from the defeat of 1849 Hungarian Fight for Freedom until the years followed by the Austro-Hungarian Compromise in 1867. For this reason, special attention is paid to the display and the reception of four well-known history paintings by three eminent Hungarian painters worthy of international recognition; namely Bertalan Székely's (1835-1910) The Discovery of the Body of King Louis II (1860) and The Women of Eger (1867), Viktor Madarász's (1830-1917) Péter Zrínyi and Ferenc Frangepán in Prison at Wiener-Neustadt (1864) and Gyula Benczúr's (1844-1920) The Baptism of Vajk (1875), analysed in a chronological order. Furthermore, the importance that these nineteenthcentury Hungarian history paintings had in the formation of Hungarian nationhood in the nineteenth century can be more successfully transmitted to foreigners with the help of a contemporary research methodology of cultural studies; it is cultural memory. As an international and interdisciplinary phenomenon connected to the names of prominent scholars like Sigmund Freud, Maurice Halbwachs, Aby Warburg, Pierre Nora and Jan Assmann, this theoretical discourse has been recognized as a device for survival of suppressed cultures threatened by extinction, which has been primarily embodied in their insistence on their antecedents' past. Meanwhile such researches have focused on, among others, peoples like the Jews by the German historian of religion, Jan Assmann (Assmann 2005), and Mexican Americans by the American cultural anthropologist and theologian Jeanette Rodriguez and Ted Fortier (Rodriguez and Frontier 2007), the Hungarians also deserve this kind of scholastic attention because the historical events of the 1850s and 1860s created such political and social situation in Hungary that history paintings became the carriers of the Hungarian nation's cultural memories.

There were series of political upheavals throughout nineteenth-century Europe, culminating in the European Revolutions of 1848 (called the Spring of Nations). Tracing back to the ideas of the French Revolution of 1789-1799, the overall aims of the suppressed and underdeveloped countries were to subvert feudal absolutism, to strengthen capitalism, and to form nation-states with bourgeois democracy - in other words, to bring their countries up to Western European standards. This 1848 revolutionary wave primarily threatened the Habsburg Austrian Empire facing with the simultaneous desperate struggles for national independence in all of her oppressed territories involving Hungary. However, the Habsburg emperor Franz Joseph I (1830-1916) succeeded in overcoming the difficulties, and, among others, the Hungarian Revolution and Struggle for Independence between $15^{\text {th }}$ March 1848 and $13^{\text {th }}$ August 1849 was defeated with the help of the Russian tsar, Nicholas I (1796-1855). After the defeat of 1849 Hungarian Fight for Independence, the integrity of Hungarian national identity was threatened by the Habsburg Austrian Empire's imperial efforts to restrict, even prevent Hungarian political and national independence until the 1860s. The reaction of the Austrian authorities to Hungary's struggles was immediate, harsh and merciless: in the autumn and winter of 1849 the intimidated country was governed by a military dictatorship led by Julius Jacob von Haynau (1786-1853) - nicknamed 'the Hyena of Brescia' - in the period called Retribution. Beginning with the execution of the first prime minister of Hungary, Lajos Batthyány (1807-1849), and the thirteen generals of the war of 
Tóth, Zsuzsanna. "The Hungarian Peculiarities of National Remembrance: Historical Figures with Symbolic Importance in Nineteenth-century Hungarian History Paintings." AHEA: E-journal of the American Hungarian Educators Association, Volume 5 (2012): http://ahea.net/e-journal/volume-5-2012

independence, ${ }^{1}$ there were altogether at least a hundred executions and over 1,500 long-term imprisonments (Kontler 1999, 264). Likewise the every day life of ordinary people was mortified by internments, denunciations of spies, even restrictions of dress habits. In the next period, called Neo-absolutism (1851-1859), Alexander von Bach (1813-1893), Austrian minister of home affairs governed Hungary under heavy state control with the help of military surveillance; his policies of centralisation and Germanisation functioned in favour of the total assimilation of the country into the Habsburg Empire. In accordance with this, Bach endorsed reactionary policies that reduced freedom of the press and abandoned public trials.

Nevertheless, in order to stabilize the precarious political situation of the Habsburg Empire because of her war losses against Italy and Prussia (in the Battle of Solferino in 1859, then the Battle of Königgrätz in 1866), Franz Joseph finally gave in, making peace with the Hungarian people by establishing the dual monarchy of Austria-Hungary. As a result, the AustroHungarian Compromise in 1867 gave Hungary back its constitutional independence, put an end to eighteen years of political abuse, and the following nearly peaceful fifty years made relatively rapid agrarian-industrial developments and an intellectual-artistic 'Golden Era' possible.

The remembrance of national past (or cultural memory) became the necessary 'shield', the cohesive power for Hungarians in order to protect their nationhood in opposition to Austrian integration. From the earliest times, marginalized communities have managed to survive a plethora of threats to their existence through their ability to interpret, adapt to and resist hegemonic cultures; which has always been based on any interpretive community's capacity to remember, to create and to re-create their past, thus their identity (Rodriguez and Frontier 2007, 4). This way of survival is completed by tradition as the collective construction, as well as an integral part of the daily life of the remembering communities, therefore its loss has usually led to the disintegration of communities (Gyáni 2000, 94). In other words, with the help of keeping past and tradition in memory, generations of a people in this case Hungarian people - have been united through time for a common cause. In accordance with Jeanette Rodriguez's argument for an eternal truth that the deeper the abyss of crisis is the greater becomes one's connection to cultural memory and to past generations (Rodriguez and Frontier 2007, xii), the dangers of Hungary's total administrative, linguistic assimilation into the Habsburg Empire induced Hungarians to look back, even to escape to their national traditions and past for the survival of the nationhood. In practice, from the end of the 1850s until the 1867 Compromise Hungary's resistance by the expression of national identity became a governing principle in every area of life. It involved the wearing of national costume (for example szür), men's growing of a so-called Kossuth-beard, the indication of national colours (red, white and green), the exclusion of Austrians in social events, even the denial of paying taxes. Moreover, as the dominant ideology and period style of the age, National Romanticism served as an appropriate political and artistic frame for the Hungarians' striving for independence. As a reaction to dynastic or imperial hegemony, National Romanticism was primarily manifest in the arts of those European countries or regions of Europe that once had been subjected to foreign artistic or political domination.

The specific technique of interpreting national past together with specific codes and symbols addressed to present compatriots were in the service of nineteenth-century Hungarian

\footnotetext{
${ }^{1}$ Arisztid Dessewffy (1802-1849), Ernő Kiss (1799-1849), Ernő Poeltenberg (1814-1849), György Lahner (1795-1849), Ignác Török (1795-1849), János Damjanich (1804-1849), József Nagy-Sándor (1804-1849), József Schweidel (1796-1849), Károly Knezich (1808-1849), Károly Leiningen-Westerburg (1819-1849), Károly Vécsey (1807-1849), Lajos Aulich (1793-1849) and Vilmos Lázár (1815-1849) were the thirteen martyrs of Arad.
} 
Tóth, Zsuzsanna. "The Hungarian Peculiarities of National Remembrance: Historical Figures with Symbolic Importance in Nineteenth-century Hungarian History Paintings." AHEA: E-journal of the American Hungarian Educators Association, Volume 5 (2012): http://ahea.net/e-journal/volume-5-2012

remembrance. As remembrance of any national community can never be considered completely objective and reliable because certain things and events are blurred over time, others are peculiarly emphasized Rodriguez rightly argues that the power of cultural memory rests in a conscious decision to choose particular memories and to give them precedence in communal remembrance (Rodriguez and Frontier 2007, 12). Concerning nineteenth-century Hungarian efforts to remember, Emese Révész reports that by the mentality of historicism setting out from the particular conjunction of past, present and future, past referring to the present was a specific technique of interpreting national past in the age (Révész 2000, 590). In the process of interpreting historical events the historical past appeared as the key to the presents' problems and the future's pledge; moreover, at the same time, taking historical past to refer to present also functioned as special coded language in which ancient stories carried current political references or messages (ibid). Besides, each and every community builds their history into their identity as historical or political symbolical values or, in other words, idiosyncrasies which determine important aspects of a community's world view, mentality, self esteem and self identity. Concerning Hungarian history, György E. Szőnyi defined five idiosyncrasies in a chronological order: King Stephen and the question of modernisation, King Matthias and the question of national success, the Shield of Christianity, wars of independence and internal fights, and the difference between the urban and the rural (Szönyi 1992, 30-36). All of these themes have been important constituters of the Hungarian national consciousness.

Although the Austrian censorship made the circulation of Hungarian people's cultural memories difficult in the Habsburg Empire, historical images proved to be suitable medium for transmitting secret codes and approaches to current political issues. While the majority of thinkers and artists had to emigrate or were imprisoned, the cultic reverence of 1848-1849 was soon elevated to moral-political ideal because the public remembrance of the event was strictly forbidden and punished by the absolutist Viennese authorities (Gyáni 2000, 98). The Austrian censorship expanded its 'fatherly diligence' to works of both verbal and visual cultures in order to prevent them from spreading political infection in the absolutist machinery of the Habsburg Empire. In practice, it meant that the exhibition of each work of art required its introduction to and approval of the censors. In spite of these, following William J. Thomas Mitchell's argumentation that there has always been a way of overcoming the difficulty of the imposed and artificial conditions of muteness and blindness as "the two faces of the unspeakable and unimaginable" (Mitchell 2005b, 296), Hungarian culture "compelled to develop methods of encoding politically delicate messages" in the shadow of the Austrian censorship (Kontler 1999, 266). What is really appropriate for becoming a secret code, according to Mieke Bal, is pictorial narrative because "the law before which the telling of forbidden stories will be punished is largely verbal, as is the practice of jurisdiction. Pictorial narrative, in such circumstances, is a counterdiscourse" (Bal 2004, 1290). This is how history painting, the dominant form of academic painting and the noblest form of art with national, social and artistic personages of political and moral parables became one of the most important and effective assistants of national resistance by faithfully mirroring historical memories to keep national past alive during the Austrian absolutism. ${ }^{2}$ The unconcealed intention of this genre was, as Zsuzsanna Bakó argues, to influence public opinion with emotional tools, thus it had an important role in the shaping of Hungarian national consciousness (Bakó 2012). The convincing power of these pictures is based on, on the one

\footnotetext{
${ }^{2}$ Emese Révész argues that the peculiar, 'substitutional' function of these images of national history is shown by the fact that as soon as it was possible, they were followed by the representations of recent and current events (Révész 2000, 584).
} 
Tóth, Zsuzsanna. "The Hungarian Peculiarities of National Remembrance: Historical Figures with Symbolic Importance in Nineteenth-century Hungarian History Paintings." AHEA: E-journal of the American Hungarian Educators Association, Volume 5 (2012): http://ahea.net/e-journal/volume-5-2012

hand, themes rich in dramatic turns and impressive characters, as well as spectacular expression (Révész 2000, 580); on the other hand, the psychological impact of images on their audience. According to Mitchell, the reason is

Images are not just passive entities that coexist with their human hosts. They change the way we think and see and dream. They refunction our memories and imaginations, bringing new criteria and new desires into the world (Mitchell 2005a, 92).

He further argues that as human beings establish their collective, historical identity by creating around themselves a second nature composed of images that are active players in the game of establishing and changing values (op. cit., 105), vision is always a 'cultural construction' that is "learnt and cultivated, not simply given by nature" (op. cit., 337). Obviously, nineteenth-century Hungarian viewers were supposed to possess the necessary background knowledge on past and current political issues to comprehend the national messages encoded into history paintings.

By reminding the Hungarian nation of the earlier foreign abuses and national tragedies, history painters in the years following the Bach regime intended to express antipathy and resistance against Austrian domination on the one hand, and to call for national unity on the other. In the atmosphere of 1850 s absolutism the newly appearing historical paintings represented the different stations of the national story of suffering. Katalin Sinkó argues that although these works of art depicting tragic stories, failed heroes, visions of devastation and decay represent concrete historical moments from the past, their meaning and parable can be connected to the present oppression followed by the failed fight for freedom, and the sad experiences of national division (Sinkó 2000c, 598). By pointing beyond the specific moments of their representation, the 'time horizon' of these pictures' is not only the visualized historical moment, but also the lifetime of the Hungarian nation, thus historical victims such as King Louis II symbolises - beyond themselves - the subdued nation, too (ibid). The real aim of the painters must have been to hasten historical justice through evoking the nation's martyrs (ibid). Furthermore, Révész explains that while the evocation of traumatic defeats indirectly liberates constructive energies, it can directly be the catalyst of national sentiments; not only as deterrent, but also as the proof of recovery in the future (Révész 2000, 589). As a matter of fact, images upon the national story of suffering largely contributed to the formation of the peculiarities of the Hungarian national identity.

Bertalan Székely's history painting, entitled The Discovery of the Body of King Louis II (1860) (figure 1), goes back to one of the most politically decisive, as well as one of the most symbolic losses of Hungarian national history. As one of the representatives of the more lyrical trend of Romanticism, the painting represents the dramatic moment when the young king's relatively unharmed body covered by clean, white clothes is being identified, lifted out of the water, which is accompanied by the spontaneous tribute by five men of all ranks. The scene of dirty and dangerous marsh, the clouded sky with flying scavenger birds (probably ravens or crows) searching for prey, all express the hopeless situation of a vulnerable country which became the plaything of alien powers. The historical background of Székely's painting reaches back to the sixteenth century. Wladislas II (1456-1516), whose inclination to agree to any proposal put before him led to the nickname 'Dobrze' (the Polish word for 'all right'), was succeeded by his son, Louis II (1506-1526). Despite the growing Turkish threat from south-east, Bryan Cartledge says that Western Europe turned its back to Hungary leaving it without financial and military assistance against the Turks. Meanwhile Suleiman I (14941566), sultan of the Ottoman Empire, led his force from Istanbul in April 1526, the king's 
Tóth, Zsuzsanna. "The Hungarian Peculiarities of National Remembrance: Historical Figures with Symbolic Importance in Nineteenth-century Hungarian History Paintings." AHEA: E-journal of the American Hungarian Educators Association, Volume 5 (2012): http://ahea.net/e-journal/volume-5-2012

calls to arms received only a minimal and grudging response. Finally the Hungarian army consisted of some 25000 men led by Archbishop Pál Tomori of Kalocsa (1475-1526) and György Szapolyai (1488-1526). On $29^{\text {th }}$ August 1526 the three-hour battle ended in a total slaughter: over 20000 Hungarian soldiers perished there; falling from his horse King Louis drowned in the flooded stream Csele owing to his heavy armour-plating. Deprived of its king, most of its church hierarchy and many of its landowners, the medieval kingdom of Hungary ceased to exist and its territory became the battlefield of two empires, the Habsburg and the Ottoman for one and a half centuries. György E. Szönyi argues that the reoccurring idea in Hungarian history, according to which a divided nation is punished by God, thus doomed to fail, is likely to refer to the destruction of the centralised authority King Matthias Corvinus (1443-90) had previously established, the massive revival of baronial power and the renewed tension between the barons and the lesser nobility (Szőnyi 1992, 31). The plain of Mohács became the symbolic graveyard of national greatness forever, its memory as an ideologically charged historical symbol belongs to the theme of the Turkish Occupation, and the fact that Hungary's destiny seemed to have become the protection of the western states from Ottoman invasion led to a special Hungarian myth in which Hungary appears as the shield of Western Christian civilisation against the pagan conquerors (ibid).

In order to create a highly valued, eternal national memento on the canvas, Székely turned to ancient Hungarian artistic traditions. Looking behind the motives of the creation of Székely's painting, although the painter's choice of theme is obviously a reflection on the then current political circumstances and also a call for national resistance, it is not original. Sinkó calls our attention to the fact that the iconographical innovation of representing a dying hero can be connected to the name of Soma Orlai Petrich (1822-1880) who painted his picture, entitled The Discovery of the Body of Louis II, in Munich, Germany, in 1850 (Sinkó 2000a, 109). Actually, he must have been inspired by an ancient literary genre, Protestant psalms remembered as Hungary's Complaint [Magyarország panasza] (ibid). The integrity of the king's body, which can also be observed in Székely's painting, has been issue for art historical debates. On the one hand, Sinkó reports that in the 1526 report of Ferenc Sárffy, captain of the fortress of Györ, there was a big emphasis on the completeness of Louis II's corpse, which is also explained by the tradition of medieval royal funerals: till the election of the new king the royal corpse embodied the integrity of the institution of the kingdom, therefore during the long period of funeral everything was done to keep the corpse intact (Sinkó 1995b, 234). On the other hand, Petrich's aim with his above mentioned painting, according to Sinkó, must have been the representation of a historical allegory, which was backed up by a composition reminding to Pietà around the perfect body of Christ, even a version of "Jesus Christ's entombment" (Sinkó 2000d, 601). As since the mid-nineteenthcentury every eminent artist used the sacralized visualization of the hero's death (Sinkó 2000a, 109), Székely followed Petrich in visualizing the mourners paying their last respects to Louis II in Pietà composition. Székely's application to peculiar, ancient traditions of Hungarian art proved to be successful because after taking part in the 1862 World Fair in London, this painting of Székely found its way onto the walls of the Hungarian National Gallery thanks to the pressure of the contemporary audience (Sinkó 1995a, 28).

The theme of Viktor Madarász's history painting, Péter Zrínyi and Ferenc Frangepán in Prison at Wiener-Neustadt (1864) (figure 2), is a sad instance for the lack of national unity of the Hungarian people. A young and an elder men can be seen in the middle of the composition, in a prison. In the presence of the warders they are saying goodbye to each other before their execution. The original historical figures, namely Péter Zrínyi (1621-1671) and Ferenc Frangepán (1620-1671), lived in the seventeenth century characterised by the efforts to expel the Ottomans from Hungarian territory. Despite defeating the Turks at Szentgotthárd, 
Tóth, Zsuzsanna. "The Hungarian Peculiarities of National Remembrance: Historical Figures with Symbolic Importance in Nineteenth-century Hungarian History Paintings." AHEA: E-journal of the American Hungarian Educators Association, Volume 5 (2012): http://ahea.net/e-journal/volume-5-2012

Leopold I (1640-1705), Habsburg Emperor of Hungary, sued for peace with the Ottoman Empire, which he secured for twenty years in the Treaty of Vasvár in 1664. It raised huge indignation in not only Hungary, but also Europe. According to Cartledge, "seen through Hungarian eyes, the treaty represented a deliberate attempt to weaken Hungary, as a prelude to the final destruction of the Hungarian constitution" (Cartledge 2006, 114). The bitter disillusionment in this passive policy towards the Turks and in the Habsburg absolutist efforts found expression in the unfocused and disorganised Wesselényi conspiracy (1666-1671) which aimed to find a foreign protector for Hungary or to create an independent Hungary. The conspiracy included Palatine Ferenc Wesselényi (1605-1667), Péter Zrínyi - the brother of Miklós Zrínyi (1620-1664) - his brother-in-law, Ferenc Frangepán, György Lippay (160066), Ferenc Nádasdy (1625-1671) and Ferenc Rákóczy (1645-1676); all of whom represented the most well-known, Catholic families in Hungary, till that moment friendly to the Austrians and loyal to the Habsburg court. Unfortunately, there was no significant support, and the conspirators could not maintain secrecy and constantly betrayed one another to Vienna - just as Zrínyi and Frangepán throw themselves on the mercy of Leopold I who ordered the arrest of all those involved. In 1671 Zrínyi, Frangepán and Nádasdy were executed in Wiener Neustadt [Bécsújhely]. Although the practical result of the Wesselényi conspiracy was savage reprisals against the Hungarian nobility, they did not capitulate. In accordance with these historical antecedents, the symbolic importance of Madarász's painting is rooted in the fact that from the seventeenth century to 1848 (and further in the modern age) there were several attempts to regain Hungary's national independence, unfortunately in vain. Szőnyi states that in the nineteenth century:

Hungarian intellectuals, poets and artists were desperately looking for the reasons and causes of the recurring failures. The emotional answer would be: God has been punishing the Hungarians for being divided, treacherous, engaging in internal fights in stead of concentrating their energy against the outer enemies. This was a typically romantic answer to the painful questions, (...) (Szönyi 1992, 32).

For these reasons, Madarász's theme can be identified with the Hungarian idiosyncrasy of Wars of Independence and Internal Fights.

Despite Madarász's idealization of Péter Zrínyi and Ferenc Frangepán as morally pure figures and the victims of political dissension in Hungarian visual remembrance, the exposition of his painting was problematic. The reason for the painter's choice of Zrínyi and Frangepán as characters relates to their social status and the consequence of their deeds. Ernö Marosi argues that as the historical interest in the nineteenth century required more authentic, more sophisticated characterization, Madarász pursued to create this kind of type by endowing individuals with features embodying communal ethos more specifically, and also reflecting the individual temper nearly psychologically (Marosi 2000, 17). However, interest distinct from dynastic history in epoch-making heroes visualizing the moral values of the national community was more significant; the inspiration of their choice was primarily the historical textual tradition, and as their representative tradition was not as continuous as that of the royal portrayal, the more obvious means of their visualization was the "idealportraiture" (ibid). The idealization of the two noblemen, Zrínyi and Frangepán, is further proven by this painting's religious overtone. Júlia Szabó points out that the picture resembles to a scene in which a frightened youth, Ferenc Frangepán, and a more resolute man, Péter Zrínyi, exchange their ideas and feelings in a long dialogue before their death (Szabó 1985, 212). The religious precedence of this scene was the parting of Saint Peter and Saint Paul 
Tóth, Zsuzsanna. "The Hungarian Peculiarities of National Remembrance: Historical Figures with Symbolic Importance in Nineteenth-century Hungarian History Paintings." AHEA: E-journal of the American Hungarian Educators Association, Volume 5 (2012): http://ahea.net/e-journal/volume-5-2012

before their martyrdom, which had been a favourite subject among painters of the early nineteenth century (ibid). Nevertheless, the current political situation in the early 1860 s made both the creation and the reception of Péter Zrinyi and Ferenc Frangepán in Prison at Wiener-Neustadt difficult due to its obvious anti-Habsburg message. On the one hand, Sinkó declares that in the atmosphere of 1850s absolutism it was not possible to hold public discourses on the Wesselényi-conspiracy itself in which the public opinion saw the heroes of a legitimate struggle against the Habsburg absolutism; therefore, for the fear of political censorship Madarász did not dare to paint the ornament of the two-headed eagle of the window (Sinkó 2000b, 610). It was rather after the Austro-Hungarian Compromise that the majority of historical and literary writings appeared (ibid). On the other hand, although neither the Art Society of Pest [Müegylet], nor the Society for the Forming of the National Gallery [Nemzeti Képcsarnokot Alakító Egylet] launched collection to acquire Madarász's painting owing to its topic, as the present of Count Miksa Teleki (1812-1872) it still got into the Hungarian National Museum in 1868 (Sinkó 1995b, 235).

Under the new political circumstances brought by the Austro-Hungarian Compromise, the manifold function of history paintings was to fill Hungarian people with hope in a better future based on the cooperation with the Austrians. By the middle of the 1860s the rigour of Habsburg Neoabsolutism was gradually softening, the political relationship between the Austrians and the Hungarians became less and less strained, which finally led to the 1867 Austro-Hungarian Compromise. This new political situation gave new aims and missions to the genre of history painting. On the one hand, Zsuzsanna Bakó says that artists were expected to justify the Compromise and to propagate monarchical ideals (Bakó 2012). On the other, nineteenth-century art primarily focused on the golden ages of national greatness and independence, too, which, according to Marosi, were always allegories: the intentions of the present were projected onto the past; and the more effective they were, the more authentic their historical character seemed (Marosi 2000, 24). The reason is, he explains, the historical person as the subject to act of the past events was comprehended as allegorical representation whose res gestae [things done] constituted the object of historical narratives (op. cit., 16). Furthermore, Révész argues that the introduction of outstanding characters or glorious events of the past as "victorious march" and the emotional identification with national heroes encouraged the lethargic national spirit on the one hand, and they also provided ways for the public, collective self-representation of the Hungarian community and for the proof of their own historical continuity on the other (Révész 2000, 588-589).

Bertalan Székely's picture, entitled The Women of Eger (1867) (figure 3), depicts one of the few victorious battles of Hungary under a one and a half hundred-year foreign domination. By the culmination of the Battle of Eger (1552) against Turkish troops outnumbered the Hungarian defenders and by the last days of the battle, the number of the male defenders were reduced so much that women also had to join the fighting. The historical antecedents of this battle are rooted in an already discussed national tragedy in the analysis of Székely's other painting and in the Turkish Conquest which began with the occupation of the capital, Buda, in 1541 till the country's Habsburg "liberation" between 1686 and 1699. During the era following the tragedy of Mohács in 1526, there were two opposing parties fighting for the Hungarian crown with sword and lies: one consisted of the Szapolyai family, John I (1487-1540), Voivode of Transylvania, and his son, John II (1540-1571); the other one was Ferdinand (1503-1564) of the Habsburgs. After Suleiman I (1494-1566) occupied the greatest part of Balkan Peninsula and Hungary's southern and middle part, in 1552 he set to expand the Ottoman territory, with a goal of occupying Vienna, capital of the Habsburg Empire. For this, first, he had to destruct the Hungarian border, existing since the Turkish occupation of Buda in 1541. After Ali, Pasha of Buda, had captured Veszprém and Vice 
Tóth, Zsuzsanna. "The Hungarian Peculiarities of National Remembrance: Historical Figures with Symbolic Importance in Nineteenth-century Hungarian History Paintings." AHEA: E-journal of the American Hungarian Educators Association, Volume 5 (2012): http://ahea.net/e-journal/volume-5-2012

Vizier Ahmed Pasha had taken Temesvár; the two armies were united in Szolnok, and then marched to Eger, called the gateway to Upper Hungary. Though the expected relief force never came, the defenders (a small garrison and the town people), commanded by István Dobó (1502-1572) resisted to the more numerous, but exhausted Turks for a heroic thirtyeight days till the onset of winter. The heroism of the women of Eger accompanied the theme of Dobó's heroic struggle against the Ottoman. The first siege in which the Turkish main forces had failed in Hungary instilled, according to István Gy. Tóth, an undying spirit into the Hungarians, but this did not alter the fact that in the 1552 Ottoman campaign the Habsburgs seemed to be unable to protect Hungary from the pagan attacks (Tóth 2005, 194). After all, it is not surprising to state that the strength of Székely's monumental painting lies in the political symbolic value of Hungary as the Shield of Christianity against the pagan conquerors, which derived from the 150-year Turkish occupation.

With the intention to fight on and to memorize the Hungarian nation's patriotism, Székely's painting became especially popular among female compatriots. The theme of this image is self-sacrificing women in the traditional feminine roles of mothers or wives. The central figure in the middle of Székely's composition is, in Sinkó's report, "the Amazon grabbing the sword from the hands of her falling husband" (Sinkó 1995b, 236). For Székely the guiding principle was that a woman should remain feminine under any circumstances; for this reason, the painter derived the anger of his central figure from love: while she is revenging her husband, her left hand is holding the hand of her dying husband, her right hand is taking the sword out of his hand (op. cit., 235). Accordingly, Révész argues that the elaboration of the feminine ideals of Hungarian national history helped the development of women's national identity, and by the heroic examples of their ancestors who in the mortal combat were men's equals, national history also reinforced women's social consciousness (Révész 2000, 592). In the light of these, the reception of this painting primarily concerned women so much that Women's Charitable Society of Eger and its Region [Eger és Vidéke Jótékony Nöegylet] collected money to immortalize the heroism of the women of Eger, and finally they bought Székely's painting for the Hungarian Artists' Hall of the National Museum (ibid).

Gyula Benczúr's picture, entitled The Baptism of Vajk (1875) (figure 4), evokes the beginning of Hungarian nationhood in Western Christian Europe. Painted eight years after the 1867 Austro-Hungarian Compromise, this image of a young man being baptised evokes the confrontation between heathen Hungarians and Christian missionaries. The central figure is identified with Vajk, alias Stephen I (cc. 967-1038), Hungary's first king, who gave Hungary her Western orientation, her Christian church, and her state organisation of which the central feature - the county - has survived to the present day. Vajk was baptised by Archbishop St. Adalbert of Prague (939-997) in 985, on which occasion he was given the baptismal name Stephen in honour of the original early Christian Saint Stephen (died c. A.D. 34-35). After the death of his father, Géza (c. 945-997), Stephen I claimed to rule the Hungarians by the principle of Christian divine right, while his uncle Koppány (n.d.-998) claimed the traditional right of seniority. Nevertheless, desiring to be an internationally recognised Christian king, Stephen was careful enough to undergo the most important rite of coronation before he set about dissolving the tribal alliances and begin the political unification of the Carpathian Basin (Zsoldos 2005, 49-50). The date of Stephen's coronation by Pope Silvester II (946-1003) is variously given as Christmas Day, 1000 or 1 January 1001. Beside the first king of Hungary established two archbishoprics and eight bishoprics, the status of the Church and the rules of religious observance, which constituted an important first step towards the establishment of a law-governed state (Cartledge 2006, 15). All of these supports Szőnyi's argument that embodying the most basic Hungarian idiosyncrasy, Stephen I stands for the question of 
Tóth, Zsuzsanna. "The Hungarian Peculiarities of National Remembrance: Historical Figures with Symbolic Importance in Nineteenth-century Hungarian History Paintings." AHEA: E-journal of the American Hungarian Educators Association, Volume 5 (2012): http://ahea.net/e-journal/volume-5-2012

modernisation as well as that of compromise; the reason is the foundation of the Hungarian state was the first time when
the Hungarians had to face the question: accept the circumstances and modernize themselves by adapting the western model, or try to preserve the national identity, traditional ideology, and nomadic social-economic system (Szőnyi 1992, 30).

Stephen I finally opted for modernization, thus the survival of the Hungarian people. Nevertheless, the moral dilemma of a choice between traditionalism and modernisation seems to have always been recurring in Hungarian history over and over again (ibid). The Baptism of Vajk functions as a memory of the historical representation of the Hungarian state settling down after the Compromise.

Because of the double aim of Benczúr's picture to visualize self-pride for the Hungarians and to underline allegiance to the Habsburg imperial house, it enjoyed high state appreciation. According to Sinkó, in addition to a need for positive, ennobling and glorious national history, which the decorative paintings of public buildings made by state commissions had to satisfy (Mikó and Sinkó 2000b, 598), in the publications on art a consensus was formed even before the Compromise, according to which the state needed to be the customers of historical pictures and statues, as well as the patron of art (Sinkó 1995a, 30). In the light of this, József Eötvös (1813-1871), Minister of Education of Hungary and president of the Hungarian Academy of Science, supported history paintings because he believed that works of art appropriate for education should be seen at the exhibitions of the National Museum. Furthermore, illustrations made for elementary schools were ordered from Hungarian artists by Eötvös, too (ibid). The Baptism of Vajk could perfectly satisfy all these needs due to its symbolisation of the nine-hundred-year antique of the independent Hungarian statehood, the representation of Saint Stephen as the embodiment of the protective sword or shield of all Christianity, thus the most basic national symbol, and its creator who was a recognized, even celebrated painter of the Habsburg court. However, Gyáni states that it was only in the decades between the Compromise and the millennium of 1896 (the one thousandth anniversary of Hungary's existence) when the figure of Saint Stephen was dominant (Gyáni 2000, 97). ${ }^{3}$ In fact, the appreciation of Benczúr's painting was the result of not only its state support owing to its theme, but also its own artistic and aesthetic merit leading to a silver medal at the Paris world fair in 1878 (Gál 2010, 78-79).

Due to the newly established artistic institutions, the patriotic messages of the above history paintings with high artistic values became widely viewable in the Hungarian public sphere. From the nineteenth century, it was the art exhibitions and museums where the true representational forms of historical processes turned up. In parallel, to the strange question which is also the title of his book, What Do Pictures Want?, Mitchell's peculiar answer is the following: a material support, a bodily medium on the one hand; and a place "to be looked at, to be admired, to be loved, to be shown" on the other (Mitchell 2005a, 73). Sinkó argues that by the establishment of art exhibitions a new institution of artistic publicity was formed, which gave a boost to the activity of art market and art galleries; it can be said that public exhibitions, art life in modern sense, art audience and art criticism existed in Hungary since the operation of the Art Society of Pest [Pesti Müegylet] since 1840 (Sinkó 1995a, 17-18).

\footnotetext{
${ }^{3}$ After this period the figure of Árpád (c. 840-c. 907), the second Grand Prince of the Hungarians, took over Stephen's role. The reason is at the turn of the century the historical image of the Hungarian Independence Party with Protestant origins gained ground against the Catholic and pro-Habsburg approaches to history (Gyáni 2000, 97).
} 
Tóth, Zsuzsanna. "The Hungarian Peculiarities of National Remembrance: Historical Figures with Symbolic Importance in Nineteenth-century Hungarian History Paintings." AHEA: E-journal of the American Hungarian Educators Association, Volume 5 (2012): http://ahea.net/e-journal/volume-5-2012

Moreover, in the public exhibitions artists competed for greater publicity because it was important whether their works of art could be exhibited in museums, which meant the highest level of social acceptance (ibid). The national movements of the mid-nineteenth century gave the final push to the establishment of national museums. Gábor Gyáni says that developed from the museological tradition of the French Revolution of 1789-1799, historical museums were supposed to be the citadel of national culture, and the early establishment of the National Museum of Hungary in 1802 fitted into this process (Gyáni 2000, 96). The publicity of art exhibitions and museums played a significant role in how much history paintings managed to perform their task of forming Hungarian national identity. First, Mitchell says that the publicity of an artwork - let it be a Hungarian historical painting with regard to the era of Austrian absolutist oppression - always led to awakening a public sphere of resistance, struggle and dialogue (Mitchell 1994, 395). Second, for the preservation and circulation of the nation's cultural memories, it is appropriate to mention Charles R. Garoian's argument for a relationship between the museum and its visitors as a dialogic process that enables a play between the public narratives of the museum and the private narratives of the viewers (Garoian 2001, 234). In this way this institution becomes an integral part of community life.

Furthermore, thanks to the new reproductive technologies in the second half of the nineteenth-century, Hungarian history paintings worth for reproduction could enter the private sphere of ordinary people. The prohibiting regulations, the censorship, the spy network of the Austrian absolutism in the 1850s and 1860s made active political life in Hungary impossible. For this reason, as Emese Révész argues, passive resistance and withdrawal from the distorted public life of the Austrian autocracy became the devices of protest against the existing foreign power, therefore the "basic cell of society," the family as the last refuge of preserving personal autonomy was valorised (Révész 2000, 591). In parallel, in the years of the Habsburg absolutism which systematically liquidated the spaces of political publicity, private houses became the centres of slowly reviving social life (ibid). This is why from the gradual softening of the Austrian absolutism to the period followed by Austro-Hungarian Compromise, Hungarian history paintings by the best national masters of the age were reproduced through printmaking [sokszorosított grafika] that appeared in the national illustrated press, independent illustrative catalogues or books with unprecedented emphasis. Most periodicals, such as Hungary and the World [Magyarország és a Nagyvilág], Our Country and Abroad [Hazánk és a Külföld], Illustrated News [Képes Újság], The Country's Mirror [Ország Tükre] (op. cit. 582-583), published historical images in 1860 and between 1864 and 1867 (op. cit., 584). In Révész's observation, due to its large-scale industrial production and consumption, printmaking not only developed into mass culture's medium, but it also possessed the greatest propagandistic power that was able, on the one hand, to mediate information to a wide and heterogeneous audience because of its integration into people's private sphere; on the other hand, to simultaneously transmit visual messages in order to acquire collective myths on honourable events, scenes, exemplary individuals and their cultic rites, and to reinforce national consciousness (op. cit., 580).

To sum up this article, the genre of history painting in the era of National Romanticism proved to be excellent medium for preserving the national past of Hungary in accordance with the present political situation from the 1850 s to the $1860 \mathrm{~s}$; therefore certain kings, noblemen and common people, all of them evoking national symbolic values, could become part of the Hungarian visual heritage. After the defeat of 1849 Hungarian Fight for Independence, the Habsburg Austrian Empire's imperial efforts threatened Hungarian nationhood until the 1860 s, against which the remembrance of national past - as cultural memory - provided necessary protection. It was materialized in images on history which, despite the Austrian censorship, succeeded in transmitting particular, secret messages 
Tóth, Zsuzsanna. "The Hungarian Peculiarities of National Remembrance: Historical Figures with Symbolic Importance in Nineteenth-century Hungarian History Paintings." AHEA: E-journal of the American Hungarian Educators Association, Volume 5 (2012): http://ahea.net/e-journal/volume-5-2012

addressed to Hungarians. After the Bach regime the purpose of history painters was to call for national unity to raise resistance against Habsburg domination, for which the most outstanding examples are Bertalan Székely's The Discovery of the Body of King Louis II (1860) and Viktor Madarász's Péter Zrínyi and Ferenc Frangepán in Prison at WienerNeustadt (1864). However, the Austro-Hungarian Compromise in 1867 created new political circumstances, therefore the national aspiration of resistance was gradually substituted by that of cooperation, and paintings reminded the nation of its glorious past in parallel with their present liaison with the Habsburg Empire. The most characteristic artworks of this purpose are Bertalan Székely's The Women of Eger (1867) and Gyula Benczúr's The Baptism of Vajk (1875). The effectiveness of history painting as medium was further reinforced by the era's newly established artistic institutions and new reproductive technologies of artworks which made it possible that the national remembrance of patriotic past and present aspirations could reach all layers of nineteenth-century society. Besides, throughout the teaching of nineteenthcentury Hungarian history painting to foreigners, even though it might be more advantageous to compare the symbolic figures with historical origins of Hungary to those of Western European or American countries (for instance England, France or the United States of America), the difference between the formations of nationhood in Hungarian versus Western countries make it difficult, even impossible to realize. The reason is the long-term political subordinated status of the Hungarian nation under the Turkish conquest and the Habsburg domination, all of which rather places the fate of nineteenth-century Hungary in parallel with the history of (post)colonized nations. This is why the theoretical discourse of cultural memory emerges as a way of placing Hungarian art into international context.

\section{Illustrations}

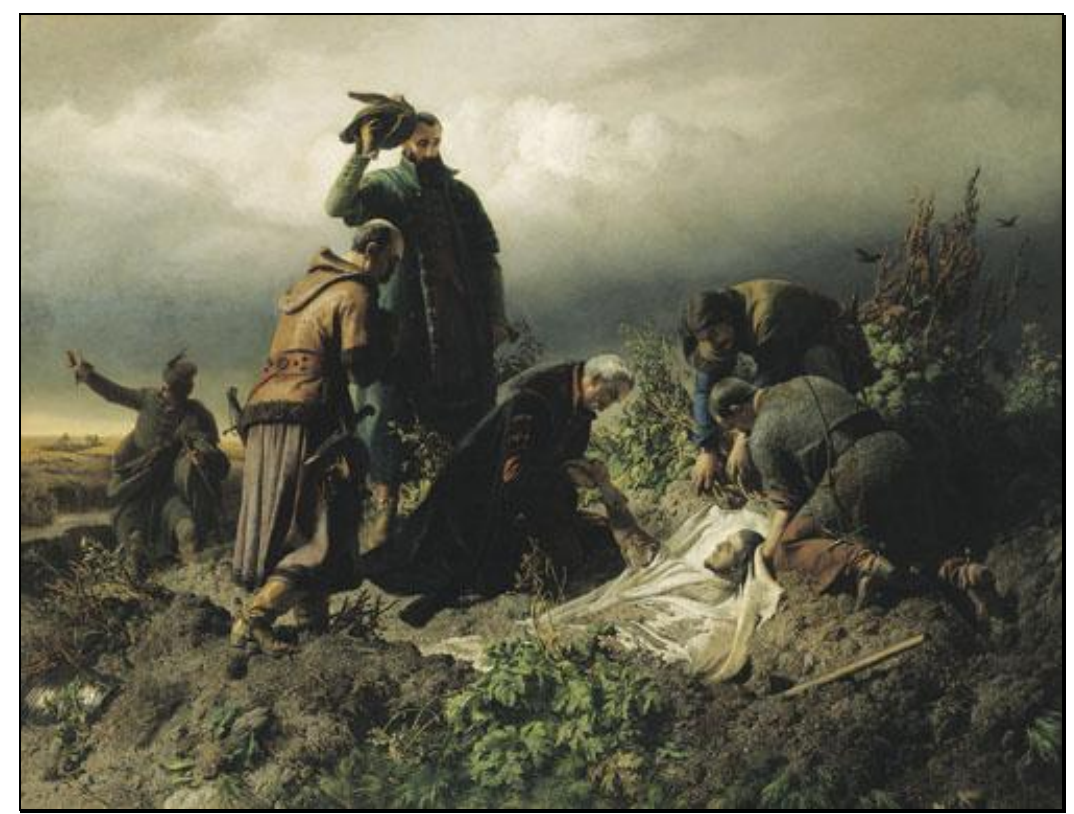

Figure 1

Bertalan Székely. The Discovery of the Body of King Louis II (1860).

Oil on canvas, 140 x 184 cm. Source: Hungarian National Gallery, Budapest, Hungary. 
Tóth, Zsuzsanna. "The Hungarian Peculiarities of National Remembrance: Historical Figures with Symbolic Importance in Nineteenth-century Hungarian History Paintings.” AHEA: E-journal of the American Hungarian Educators Association, Volume 5 (2012): http://ahea.net/e-journal/volume-5-2012

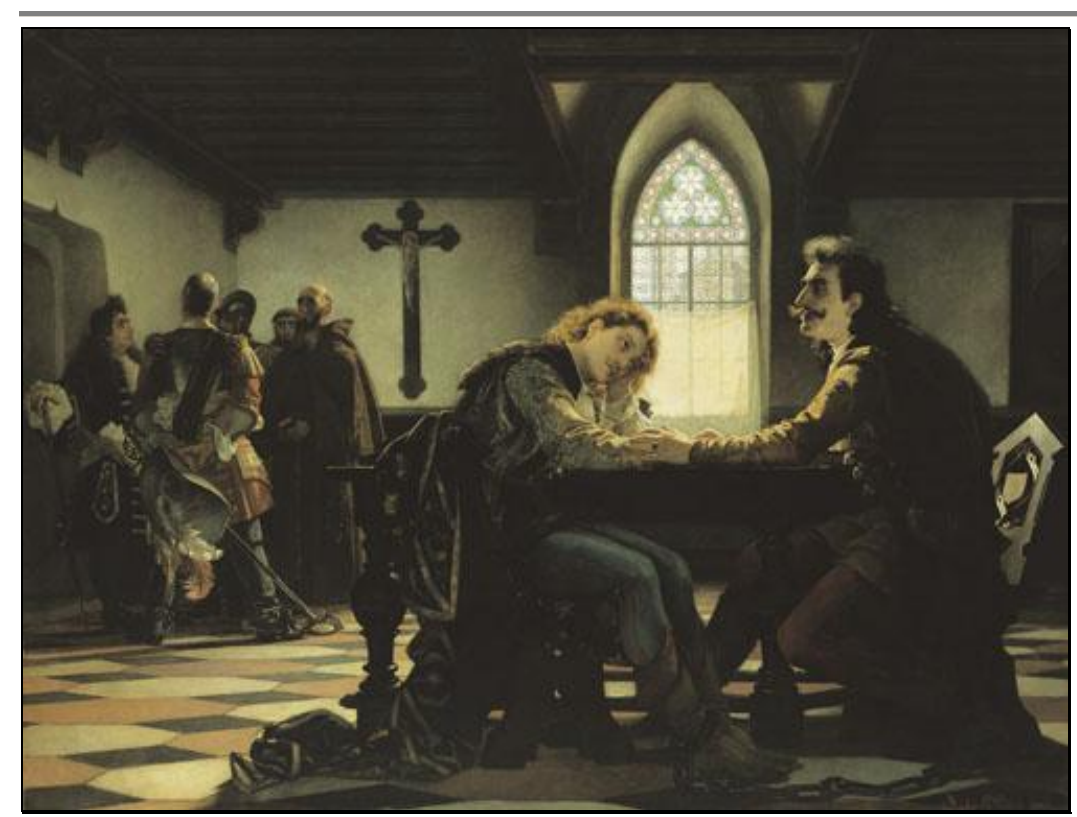

Figure 2

Viktor Madarász. Péter Zrínyi and Ferenc Frangepán in Prison at Wiener-Neustadt (1864). Oil on canvas, 177 x 234 cm. Source: Hungarian National Gallery, Budapest, Hungary.

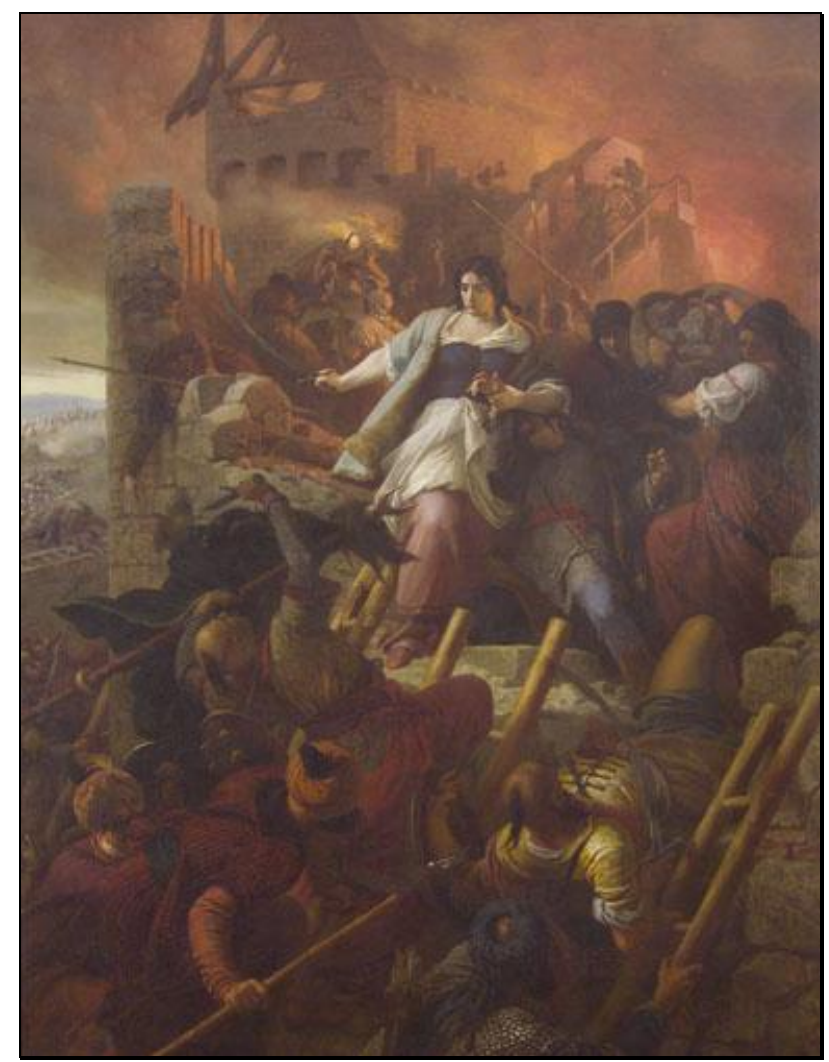

Figure 3

Bertalan Székely. The Women of Eger (1867).

Oil on canvas, 227 x 176.5 cm. Source: Hungarian National Gallery, Budapest, Hungary. 


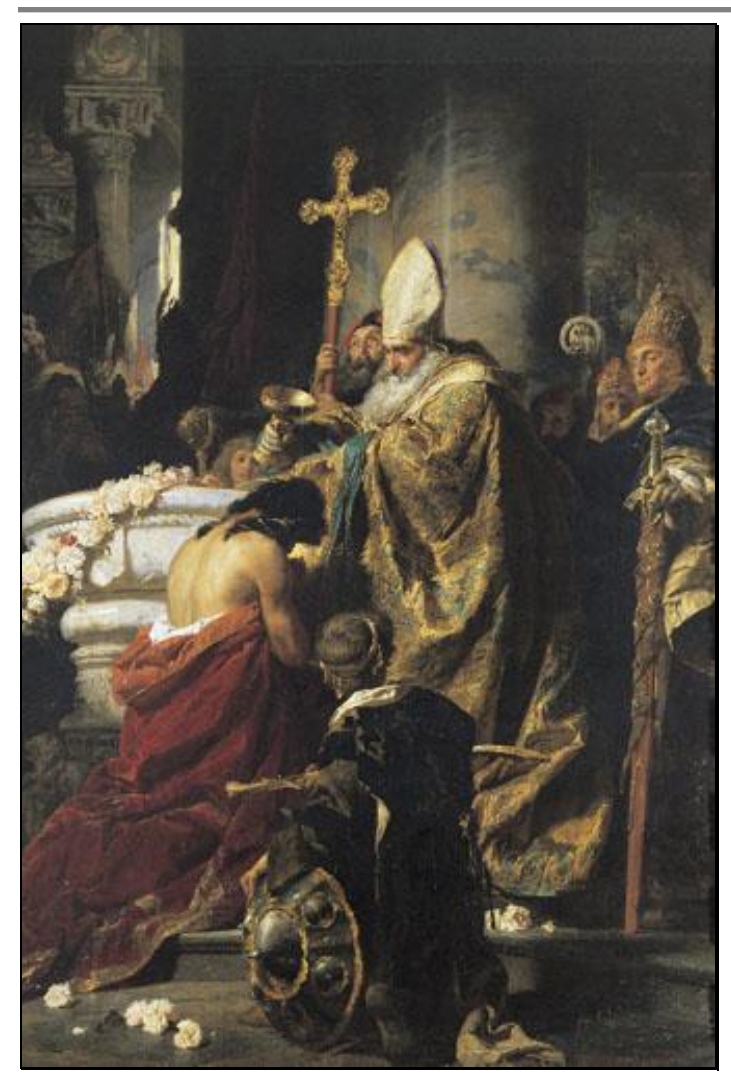

Figure 4

Gyula Benczúr. The Baptism of Vajk (1875).

Oil on canvas, 358 x 247 cm. Source: Hungarian National Gallery, Budapest, Hungary.

\section{Works Cited}

Assmann, Jan. 2005. Religion and Cultural Memory: Ten Studies. Stanford, California: Stanford University Press.

Bakó, Zsuzsanna. 2012. "History painting in the nineteenth century" ["Történelmi festészet a 19. században"]. In History Painting in the $19^{\text {th }}$ Century [Történelmi festészet a 19. században]. Available: 〈http://www.hung-art.hu/vezetes/tortenel/tartalom.html>. Access: 21 July 2012.

Bal, Mieke. Oct. 2004. "Figuration," Modern Language Association, Vol. 119, No. 5: 12891292.

Bellák, Gábor et al eds. 1995. Golden Medals and Silver Wreaths. The Cult of Art and Patronage in Hungary in the $19^{\text {th }}$ Century. [Aranyérmek, ezüstkoszorúk. Müvészkultusz és müpártolás Magyarországon a 19. században]. Budapest: Magyar Nemzeti Galéria és Pannon GSM.

Cartledge, Bryan. 2006. The Will to Survive. A History of Hungary. London: Timewell Press. Gál, Vilmos. 2010. Hungary at the World Fairs 1851-2010. Budapest: Holnap Kiadó.

Garoian, Charles R. Spring 2001. "Performing the Museum," National Art Education Association, Vol. 42, No. 3: 234-248.

Gyáni, Gábor. 2000. "Historiography: the science of national memory?" ["Történetírás: a nemzeti emlékezet tudománya?"]. In Árpád Mikó and Katalin Sinkó eds. 2000. History-image...[Történelem-kép...]. Budapest: Magyar Nemzeti Galéria and Pannon GSM, 92-102.

Kontler, László. 1999. Millennium in Central Europe. A History of Hungary. Budapest: Atlantisz. 
Tóth, Zsuzsanna. "The Hungarian Peculiarities of National Remembrance: Historical Figures with Symbolic Importance in Nineteenth-century Hungarian History Paintings.” AHEA: E-journal of the American Hungarian Educators Association, Volume 5 (2012): http://ahea.net/e-journal/volume-5-2012

Marosi, Ernő. 2000. "The images of Hungarian history. The illustration of historicity in the arts" [“A magyar történelem képei. A történetiség szemléltetése a müvészetekben”]. In Árpád Mikó and Katalin Sinkó eds. 2000. History-image...[Történelem-kép...]. Budapest: Magyar Nemzeti Galéria and Pannon GSM, 11-33.

Mikó, Árpád and Katalin Sinkó eds. 2000a. History-image. Excerpts from the Connection between Past and Art in Hungary [Történelem-kép. Szemelvények múlt és müvészet kapcsolatából Magyarországon]. Budapest: Magyar Nemzeti Galéria and Pannon GSM.

2000b. "The images of the national story of suffering" ["A nemzeti szenvedéstörténet képei”]. In Árpád Mikó and Katalin Sinkó eds. 2000. History-image...[Történelemkép...]. Budapest: Magyar Nemzeti Galéria and Pannon GSM, 598.

Mitchell, W. J. T. 1994. Picture Theory: Essays on Verbal and Visual Representation. Chicago: University of Chicago Press.

_ _ _ . 2005a. What Do Pictures Want? The Lives and Loves of Images. Chicago: University of Chicago Press.

_ _ _. 2005b. "The Unspeakable and Unimaginable: Word and Image in a Time of Terror." ELH 72, Number 2, Summer 2005: 291-308.

Révész, Emese. 2000. "Historical image as press illustration (1850-1870)" [“Történeti kép mint sajtóillusztráció (1850-1870)"]. In Árpád Mikó and Katalin Sinkó eds. 2000. History-image...[Történelem-kép...]. Budapest: Magyar Nemzeti Galéria and Pannon GSM, 580-597.

Rodriguez, Jeanette and Ted Fortier. 2007. Cultural Memory. Resistance, Faith, and Identity. Austin, University of Texas Press.

Sinkó, Katalin. 1995a. "The anatomy of artistic success: 1840-1900” [“A müvészi siker anatómiája 1840-1900”]. In Gábor Bellák et al. 1995. Golden Medals and Silver Wreaths... [Aranyérmek, ezüstkoszorúk...]. Budapest: Magyar Nemzeti Galéria and Pannon GSM, 15-47.

. 1995b. "The acquisitions of the Art Society of Pest, the Society for the Forming of the National Gallery and the Society of Fine Art for the National Museum" ["A Pesti Mủegylet, a Nemzeti Képcsarnokot Alakító Egylet és a Képzőmüvészeti Társulat vásárlásai a Nemzeti Múzeum számára”]. In Gábor Bellák et al. 1995. Golden Medals and Silver Wreaths... [Aranyérmek, ezüstkoszorúk...]. Budapest: Magyar Nemzeti Galéria and Pannon GSM, 223-240.

. 2000a. "Historicism - anti-historicism" ["Historizmus - antihistorizmus"]. In Árpád Mikó and Katalin Sinkó eds. 2000. History-image...[Történelem-kép...]. Budapest: Magyar Nemzeti Galéria and Pannon GSM, 103-115.

. 2000b. "Péter Zrínyi and Ferenc Frangepán in Prison at Wiener-Neustadt from 1681 a draft" ["Zrínyi és Frangepán a bécsújhelyi börtönben, 1681-ben - vázlat”]. In Árpád Mikó and Katalin Sinkó eds. 2000. History-image...[Történelem-kép...]. Budapest: Magyar Nemzeti Galéria and Pannon GSM, 609-610.

. 2000c. "The Baptism of Vajk (the baptism of Saint Stephen I)" ["Vajk megkeresztelése (Szent István megkeresztelése)"]. In Árpád Mikó and Katalin Sinkó eds. 2000. History-image ... [Történelem-kép...]. Budapest: Magyar Nemzeti Galéria and Pannon GSM, 641-642.

. 2000d. "The Finding of the Body of Louis II Fallen at Mohács" [“A Mohácsnál elesett II. Lajos testének feltalálása”]. In Árpád Mikó and Katalin Sinkó eds. 2000. History-image...[Történelem-kép...]. Budapest: Magyar Nemzeti Galéria and Pannon GSM, 600-601.

Szabó, Júlia. 1985. Painting in Nineteenth Century Hungary. Budapest: Corvina. 
Tóth, Zsuzsanna. "The Hungarian Peculiarities of National Remembrance: Historical Figures with Symbolic Importance in Nineteenth-century Hungarian History Paintings.” AHEA: E-journal of the American Hungarian Educators Association, Volume 5 (2012): http://ahea.net/e-journal/volume-5-2012

Szőnyi, György Endre. 1992. "Hungarian Idiosyncrasies Explained to Foreigners.” In György Kukovecz ed. 1992. Teaching Modern European History. Experiences and Prospects. An International Tempus Workshop. Szeged: JATEPress, 29-36.

Tóth, István György ed. 2005. A Concise History of Hungary. The History of Hungary from the Early Middle Ages to the Present. Budapest: Corvina. . 2005. "Hungary in the Early Modern Period." In István György Tóth ed. 2005. A Concise History... Budapest: Corvina, 181-328.

Zsoldos, Attila. 2005. "Hungary under the Árpáds and Angevins (950-1382).” In István György Tóth ed. 2005. A Concise History... Budapest: Corvina, 43-112. 